\title{
DETERMINATION Of TOTAL FLAVONOID LEVELS on LEAF STALKS ETHANOL EXTRACT Of TARO (Colocasia esculenta[L.]Schott)
}

\author{
Novena Yety lindawati ${ }^{1}$,Anni Solikhah ${ }^{2}$ \\ ${ }^{1}$ Undergraduate Pharmacy, Sekolah Tinggi Ilmu Kesehatan Nasional, Yos Sudarso 338 \\ Surakarta, 57155, Indonesia, \\ 2Diploma Pharmacy, Sekolah Tinggi Ilmu Kesehatan Nasional, Yos Sudarso 338 Surakarta, \\ 57155, Indonesia \\ Corresponding author : novena_yl@yahoo.com
}

\begin{abstract}
Taro is plant that has a pseudostalk,cylindrical and light brown bulbs. The shape of leaf is the heart in length. Leaf stalk of taro contains are saponins, flavonoids, tanins, alkaloids, steroids and terpenoids. Leaf stalk of taro can be used as an alternative medicines wound and antioxidants. Flavonoids have an important role in the biological activity of taro leaf stalk. This research aims to determine the flavonoid and total flavonoids content in the taro leaf stalk extract. The extraction is done using maceration method with $70 \%$ ethanolas solvent. The extract which is got is used for qualitative and quantitative analysis. Quercetin used as a standard solution. Quantitative analysis using UV-Vis Spectrophotometry on a wavelength of $435.5 \mathrm{~nm}$ and operating time at the $29^{\text {th }}$ minute. The results of qualitative test showed that the extract was positive flavonoids. The average concentrations of total flavonoids was $10,2223 \mathrm{mg} \mathrm{QE} /$ gram extract with \%CV value of $0,3051 \%$.
\end{abstract}

Keywords:Leaf stalk of taro, total flavonoid, quercetin, UV-Vis Spectrophotometry

\section{Introduction}

One of the medicinal plants used by the community to cure various diseases such as inflammation of purulent skin, ulcers, blood defects, scalded water, itching, diarrhea, new wound dressing and as an alternative medicine for wounds, namely taro plants (Dalimartha, 2006). Taro plants are food crops in the form of chronic herbs included in the tribe of taro-taro (Araceae). All parts of the taro plant are thought to function as an alternative wound medicine. The stalk leaves are often used as a new wound dressing or as an alternative wound medicine (Dalimartha, 2006). Taro leaf stalks can be used as vegetables, which are often called lompong vegetables. There are still many people who do not know of the benefits of taro leaf stalks as a vegetable or for treatment. The community only uses part of the tubers, while the taro leaf stalks are removed or as waste.

Taro plants are thought to have content including flavonoids and saponins (Biren, Nayak, Bhatt, Jalalpure, Seth, 2007). Research conducted by Wijaya et al. (2014) concerning "The potential of ethanol extract of taro leaf stalks (Colocasia esculenta [L.] Schott) as an alternative medicine for rabbit skin wounds (Oryctolagus cuniculus)" showed that extracts of taro leaf stalks could 
potentially be an alternative to incision wounds so phytochemical tests were also carried out. which showed that extract of taro leaf stalks contained saponins, flavonoids, tannins, alkaloids, steroids and terpenoids.

Flavonoids are compounds consisting of 15 carbon atoms which are generally distributed in the plant world. Flavonoids are widespread in plants and have many functions. Flavonoids are almost present in all parts of the plant including fruit, roots, leaves, stems, outer bark. A number of medicinal plants containing flavonoids have been reported to have antioxidant, antibacterial, antiviral, anti-inflammatory, anti-allergic and anti-cancer activities (Miller, 1996). Flavonoids are polyphenol compounds that function as antibacterial compounds by forming complex compounds

\section{Methods}

\section{Tools and materials}

The tools used are maceration vessel, rotary evaporator (IKA HB 10 basic), UVVis Spectrophotometer (Shimadzu UV mini1240), analytic scales (Ohaus, EP214), technical scales (Acis BC 500), cuvettes (HELMA brands), silica GF 254, chamber, measuring pipette (pyrex), drop pipette, push ball, glass beaker (pyrex), small test tube, test tube rack, pyrex $10.0 \mathrm{~mL} ; 25 \mathrm{~mL} ; 100 \mathrm{~mL}$, blender, stirring rod, evaporating cup, chamber cover, spotting bottle, watch glass, tweezers, spatter, tray, stopwatch, spiritus burner.

The ingredients used are: taro leaf stalk, ethanol $70 \%$ pa (Bratacem), methanol pa (Bratacem), spiritus, allumunium (III) chloride pa (E. Merck), potassium acetate pa (E. Merck), concentrated $\mathrm{HCl}$ (E Merck), $\mathrm{HCl}$ (E. Merck), metal $\mathrm{Mg}$, aquades, quercetin standard (Aldrich Chemistry), mobile phase (toluene pa: ethylacetate pa: ethanol pa (3: 3: 0.5)).

\section{Sample Preparation}

$7.5 \mathrm{~kg}$ taro leaf stalks are sorted then washed thoroughly, then drained. Taro leaf stalks are cut into small pieces and then dried with sunlight with black cloth covered for \pm 3-5 days. Then blended to form a powder.

Making ethanol extract of taro leaf stalks

The manufacture of ethanol extract of taro leaf stems was carried out by maceration method which was 320 grams of taro leaf against extracellular proteins that interfere with the integrity of bacterial cell membranes (Dwidjoseputro, 1994).

The flavonoid content of the extract of taro leaf stalks was also shown in the study of Fadlila et al (2015) by monitoring TLC of taro leaf stalks which have antibacterial activity with the help of $\mathrm{AlCl}_{3}$ spotting scars. The results obtained indicate that there are flavonoid compounds which are characterized by changes in color on the spot from black to bright yellow. Based on the background of the presence of flavonoids qualitatively in extracts of taro leaf stalks, further research was conducted on the total flavonoid content contained in the ethanol extract of taro leaf stalks using UV-Vis spectrophotometry method.

stalk weighed and put into a maceration vessel. Added $2400 \mathrm{~mL}$ (1: 7.5 ratio) ethanol $70 \%$ until the sample is completely submerged. Stirring is done every 24 hours, then filtered using flannel. The filter results obtained are then separated between filtrate and residue. The filtrate is placed in a container and the residue is reminerated with a new solvent (ethanol70\%) as much as 800 $\mathrm{mL}(1: 2.5) \pm 2$ days. The filtrate obtained is then collected and concentrated with a rotary evaporator until a thick extract is formed.

\section{Qualitative analysis of flavonoid compounds}

Ethanol thick extract of taro leaf stalk for qualitative test is divided into 4 parts, namely A, B, C and D. Filtrat A as blank, then tested with 3 methods, namely:

a. Bate Smith-Metchalf Method: B filtrate is added with 3 drops of concentrated $\mathrm{HCl}$ then heated on a water bath, if there is a change of dark red to purple it shows positive results (Marliana et al, 2005).

b. Wilstater Cyanidin method: C filtrate is added with 2 drops of $\mathrm{HCl}$ and metal $\mathrm{Mg}$ then observed the color changes that occur. The red to orange color is given by flavone compounds, dark red is given by flavonol or flavonone, green to blue is given by aglycones or glycosides (Marliana et al, 2005).

c. TLC test using D filtrate, with silica phase GF 254, toluene mobile phase p.a: 
ethylacetate p.a: ethanol p.a 3: 3: 0.5 (Fadlila et al, 2015).

Quantitative analysis of extracts of taro leaf stalks

a. Making reagents to determine total flavonoid levels

Making 10\% $\mathrm{AlCl} 3$ solution

As much as 1 gram of $\mathrm{AlCl} 3$ powder is weighed and put into a glass beaker then dissolved with some ethanol $70 \%$ until it dissolves completely. Put it in a measuring flask of $10.0 \mathrm{~mL}$ and add ethanol $70 \%$ to the mark (Department of Health, 1995).

\section{a. Making $\mathrm{CH} 3 \mathrm{COOK} 1 \mathrm{M}$ solution}

A total of 0.9814 grams of powder Potassium acetate was weighed and put into a glass beaker and then dissolved with a portion of aquadest until it dissolved completely. Put in a measuring flask of 10.0 $\mathrm{mL}$ and add aquadest to the mark (Department of Health, 1995).

\section{Blangko Solution}

$3 \mathrm{~mL}$ methanol; $\mathrm{AlCl} 3$ 10\% $0.2 \mathrm{~mL}$; CH3COOK $1 \mathrm{M} 0.2 \mathrm{~mL}$ and add aquadest to10 $\mathrm{mL}$.

c. Preparation of quercetin standard solution

Preparation of quercetin stock standard solution 500 ppm

Weighed $50 \mathrm{mg}$ of standard quercetin standard and dissolved in $100 \mathrm{~mL}$ of methanol for 500 ppm.

b. Making quercetin work standard solution

Pipet the $1.4 \mathrm{~mL}$ (70 ppm) solution from the stock standard solution, then add 3 $\mathrm{mL}$ of methanol, $0.2 \mathrm{ml}$ of $\mathrm{AlCl} 310 \%, 0.2$ $\mathrm{mL}$ of $1 \mathrm{M}$ potassium acetate, and add to the aqua destilata to $10 \mathrm{~mL}$, put in measuring flask of $10.0 \mathrm{~mL}$.

\section{c. Determination of operating time (OT) quercetin}

Pipet the $1.4 \mathrm{~mL}$ (70 ppm) solution from the stock standard solution, then add $3 \mathrm{~mL}$ of methanol, $0.2 \mathrm{~mL}$ of $10 \% \mathrm{AlCl} 3,0.2 \mathrm{~mL}$ of 1 $\mathrm{M}$ potassium acetate, and add aqua destilata to $10 \mathrm{~mL}$, put in measuring flask of $10.0 \mathrm{~mL}$.
The absorbance solution was measured at a wavelength of $431 \mathrm{~nm}$ (Ahmad, 2015) with an interval of 1 minute, namely at $0,1,2,3,4$, 5 minutes and so on or until a stable absorbance was obtained. The operating time (OT) obtained is in the 29th minute

\section{d. Making a standard curve}

Make a series of standard solutions $(30,40,50,60,70,80,90,100,110 \mathrm{ppm})$ from the stock standard solution. Pipette 0.6 $\mathrm{mL} ; 0.8 \mathrm{~mL} ; 1.0 \mathrm{~mL} ; 1.2 \mathrm{~mL} ; 1.4 \mathrm{~mL}, 1.6 \mathrm{~mL}$, $1.8 \mathrm{~mL}, 2.0 \mathrm{~mL}, 2.2 \mathrm{~mL}$ from the stock standard solution. From each concentration 3 $\mathrm{mL}$ of methanol were added, $0.2 \mathrm{~mL}$ of $\mathrm{AlCl} 310 \%, 0.2 \mathrm{~mL}$ of $1 \mathrm{M}$ potassium acetate, and added with aqua destilata to $10 \mathrm{~mL}$, put in a measuring flask of $10.0 \mathrm{~mL}$. The solution is left in a dark place until the OT is obtained, then the absorption series of the standard solution is measured at the maximum wavelength of quercetin, starting from the smallest level.

e. Determination of flavonoid levels of ethanol extract of taro leaf stalks (Method Chang et al., 2002)

Weighed $250 \mathrm{mg}$ thick extract of base leaf stems dissolved in $25 \mathrm{~mL}$ methanol. Taken $5 \mathrm{~mL}$, add $3 \mathrm{ml}$ of methanol, $0.2 \mathrm{~mL}$ of $10 \% \mathrm{AlCl} 3,0.2 \mathrm{~mL}$ of $1 \mathrm{M}$ potassium acetate, and add it with aqua destilate to 10 $\mathrm{mL}$. The solution is placed dark until the OT was obtained, then the absorbance was measured at UV-Vis Spectrophotometry with maximum wavelength quercetin, replication 3 times and triplo replication. Total flavonoid levels in the sample were calculated using a linear regression equation.

\section{Data analysis \\ Calculation of extract extract}

The ethanol extract yield of taro leaf stalk was calculated by comparing the extract weight obtained with the starting material multiplied by $100 \%$. 


\section{Linear Regression Equations}

By using a linear regression equation which is the relationship between concentration and absorbance, resulting in values of $a, b$, and $r$. A linear curve must have an $\mathrm{r}$ value close to \pm 1 , a good $\mathrm{r}$ is 0.999 which means there is a very strong correlation between two variables, namely the variable $\mathrm{x}$ as concentration and variable $y$ as absorbance (Riyanto, 2009). Linear regression equation is calculated by the formula $\mathrm{y}=\mathrm{a}+\mathrm{bx}$. Where: $\mathrm{a}=$ constant, $\mathrm{b}$ $=$ regression coefficient, $\mathrm{y}=$ absorbance as the dependent variable (dependent variable), $\mathrm{x}=$ concentration as independent variable (independent variable). Linear regression equation is used to calculate the total flavonoid concentrations in the sample, the $\mathrm{Y}$ value is filled with the sample absorbance value and the $\mathrm{X}$ value is the total flavonoid concentration in the sample.

\section{Coefficient of Variation ( $\% \mathbf{C V}$ )}

Coefficient of Variation (\% CV) is the ratio between the standard deviation of the average of the data and expressed in $\%$. The objective is to determine the coefficient of variation, which is to see the distribution of data from the average count. The coefficient of variation was obtained from the total sample flavonoid data. A good \% CV value is less than $2 \%$ (Harmita, 2004).

\section{Results and Discussion}

\section{Making Ethanol Extract of Talas Leaf Stalk}

Wet taro leaf stalks are dried under the sun with a black cloth covered so that they dry faster, protecting the compounds contained in the taro leaf stalks that do not hold high heat directly. Drying is carried out for $\pm 3-5$ days. The taro leaf stalk is smoothed to increase contact between the solvent and the sample so that it can extract flavonoids to the maximum. The results of the simplicia powder were 342.9 grams.

$$
\text { Extraction method used is }
$$
maceration (cold extraction) to prevent damage to chemical compounds that are not resistant to heating, especially flavonoids. Maseration is an extraction method that works and the tools used are simple.
Ethanol $70 \%$ is a solvent with a mixture of ethanol and water so it is polar so it can produce an active ingredient with an optimal amount, where the impurity is only on a small scale participating in the extracting liquid (Voight, 1995). The choice of ethanol as a solvent because it is polar, has advantages such as ethanol does not cause swelling of the cell membrane and can improve the stability of the active ingredient dissolved. Ethanol is a good and universal solvent in dissolving secondary metabolites in plants so that they are able to extract polar compounds to non-polar compounds.

The maceration process is placed at room temperature and protected from light so that heat-resistant compounds are not damaged and not oxidized. Filtering is done after 5 days, which aims to separate the filtrate and residue from the sample and also separate unwanted impurities. For 2 days remaseration with new solvents (ethanol70\%) was carried out to maximize the process of extraction. The obtained filtrate was collected and concentrated with a rotary evaporator at a maximum temperature of $50^{\circ} \mathrm{C}$ and a speed of 200 $\mathrm{rpm}$. The temperature used is less than $50^{\circ}$ $C$ because to avoid damage to active substances due to the influence of high temperatures. The purpose of concentration is to separate and evaporate between the solvent and the extract obtained. The yield obtained was $25.59 \%$ b / b.

\section{Qualitative Analysis of Flavonoid Content}

Flavonoid compounds were tested using the Bate Smith-Methalf method and the Wilstater Cyanidin method. The method of Bate Smith-Metchalf is done by adding concentrated and heated $\mathrm{HCl}$. Addition of concentrated $\mathrm{HCl}$ to hydrolyze and break the glycoside bond. Heating functions to accelerate the hydrolysis reaction that occurs, where the positive results on flavonoids are indicated by the appearance of orange or red. The results showed that samples of taro leaf stalks were positive containing flavonoids with discoloration from black to green to dark red (Figures 1 and 2). 


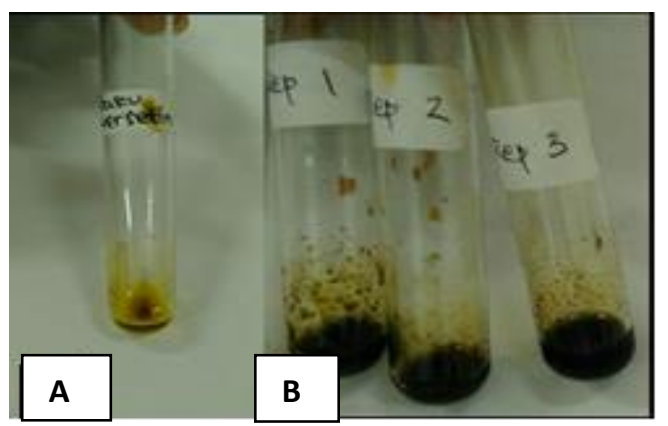

Figure 1. Test results of Bate Smith-Metchalf. (A) quercetin standard solution and (B) positive sample (replication 1,2,3) containing flavonoids<smiles>O=c1c(O)c(-c2ccccc2)oc2ccccc12</smiles>

Flavonol<smiles>COC1=C(O)c2ccccc2O[C@H]1c1ccccc1</smiles>

Flavilium salt

Figure 2. Flavonol reaction with $\mathrm{HCl}$ to form flavilium salt in the Bate Smith-Methalf test (Achmad, 1986)

The Wilstater Cyanidin method was carried out by adding $\mathrm{HCl}$ and $\mathrm{Mg}$ metal. The function of adding $\mathrm{HCl}$ to detect compounds containing benzopiranone nucleus, so that after adding $\mathrm{HCl}$ will produce benzopirylium salt which is also called flavilium salt. Reduction with $\mathrm{Mg}$ and $\mathrm{HCl}$ produces complex compounds that are orange in flavonols (Figures 3 and 4).

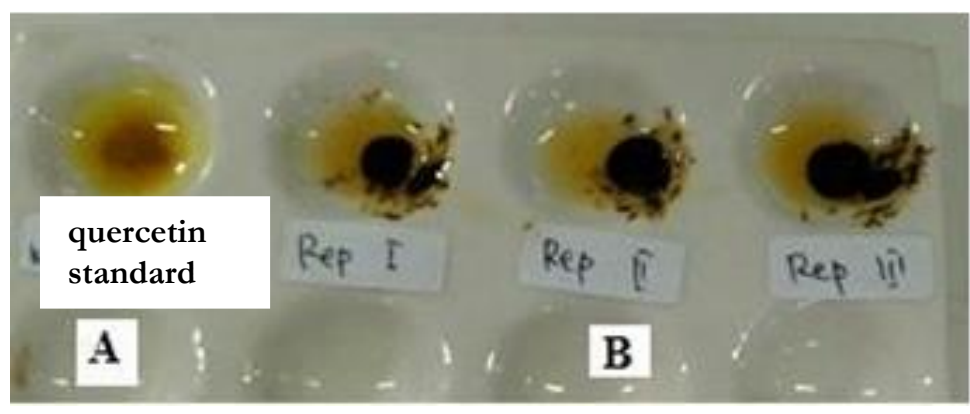

Figure 3. Results of the Wilstater Sianidin test. (A) Raw quercetin and (B) samples (replication $1,2,3)$ positively contain flavonoids 


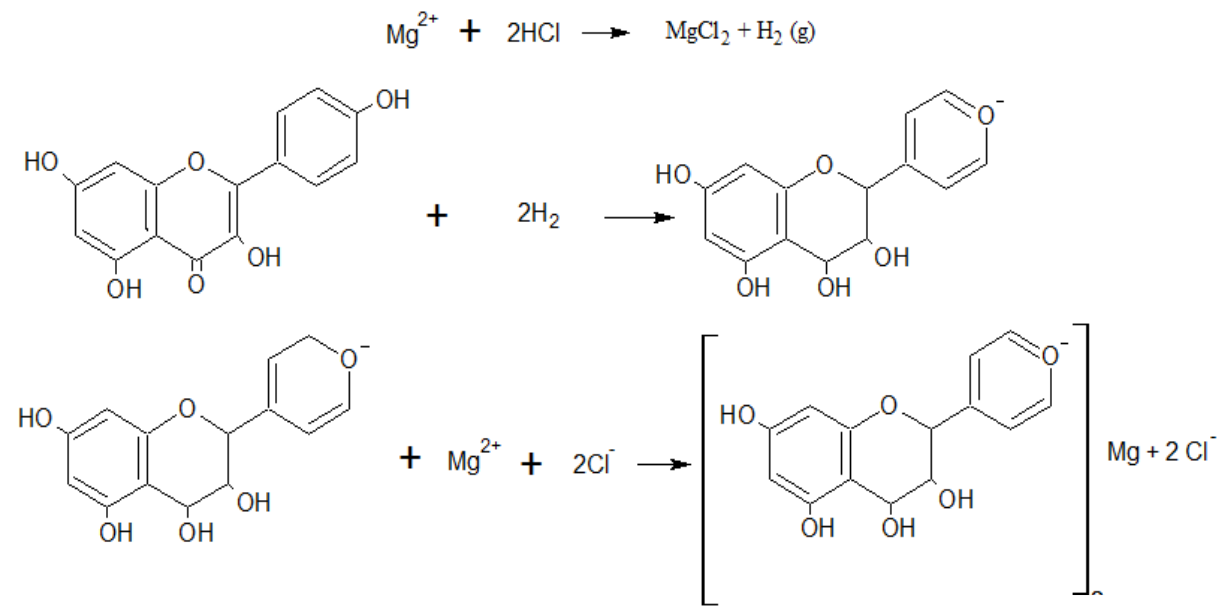

Flavilium salt

Figure 4. Flavonol reaction with $\mathrm{HCl}$ and $\mathrm{Mg}$ metal in the Wilstater Cyanidin test (Arum, 2012)

Test flavonoids are also done with TLC (Thin Layer Chromatography) to further ensure the flavonoid extracts taro leaf stalk. The TLC test results showed positive flavonoid containing in samples of taro leaf stalks. The results are shown by the same HRf value and the same spotting color from the sample compared to the quercetin comparator. HRf values in the sample and quercetin standard in 3 replications were the same, namely 59. The color change of the specks from thin yellow changed to an intense yellow color after being sprayed with $\mathrm{AlCl}_{3}$ patches. The resulting color is more intensive because of the formation of complexes with $\mathrm{AlCl}_{3}$ (Figure 5).

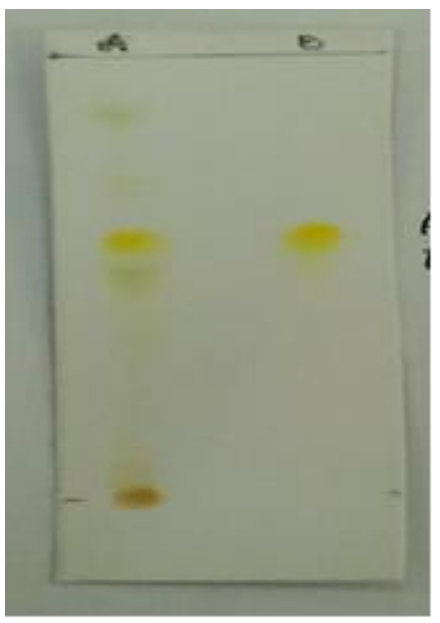

Figure 5. Results of TLC after spraying with $\mathrm{AlCl}_{3}$ solution; (A) sample (B) Quercetin standard solution, using silica phase GF 254 and mobile phase (toluene p.a: ethylacetate p.a: ethanol p.a (3: 3: 0.5))

\section{Determination of Total Flavonoids}

Analysis of total flavonoid content in extracts of taro leaf stems was carried out using UV-Vis Spectrophotometry method. In determining the Operating Time (OT) is obtained in the 29th minute. The wavelength measurement results in the Volume 1 Issue 1 (2018) maximum wavelength at $435.5 \mathrm{~nm}$. Absorption measurements with UV-Vis Spectrophotometer must be at maximum wavelength because at maximum wavelengths of absorption changes are accompanied by changes in concentration 
also at maximum conditions, absorption bands around the maximum flat wavelength, and repeated measurements with small errors, Lambert-Beer law will be fulfilled properly so that a linear calibration curve can be obtained. The results of absorbance measurements of quercetin standard solutions can be seen in table 1.

Table 1. Results of measurements of absorbance of quercetin standard solutions

\begin{tabular}{ccc}
\hline Concentration $(\mathrm{ppm})$ & Absorbance & Linear regression value \\
\hline 30 & 0,2302 & \\
40 & 0,2922 & \\
50 & 0,3821 & \\
60 & 0,4558 & $\mathrm{y}=-0,0005+0,0075 \mathrm{x}$ \\
70 & 0,5077 & $\mathrm{r}=0,9984$ \\
80 & 0,6027 & \\
90 & 0,6814 & \\
100 & 0,7490 & \\
110 & 0,8284 & \\
\hline
\end{tabular}

Based on the results of the determination of the absorbance of quercetin standard solutions can be described in the calibration curve (figure 6). Calibration curve of quercetin standard solution obtained a linear relationship between absorbance and concentration as indicated by the results of linearity values of 0.9984. This linearity value is close to 1 so it can be said that absorbance and concentration have a very strong correlation. The linear regression equation used for calculating levels is $\mathrm{y}=-0.0005+$ $0.0075 \mathrm{x}$.

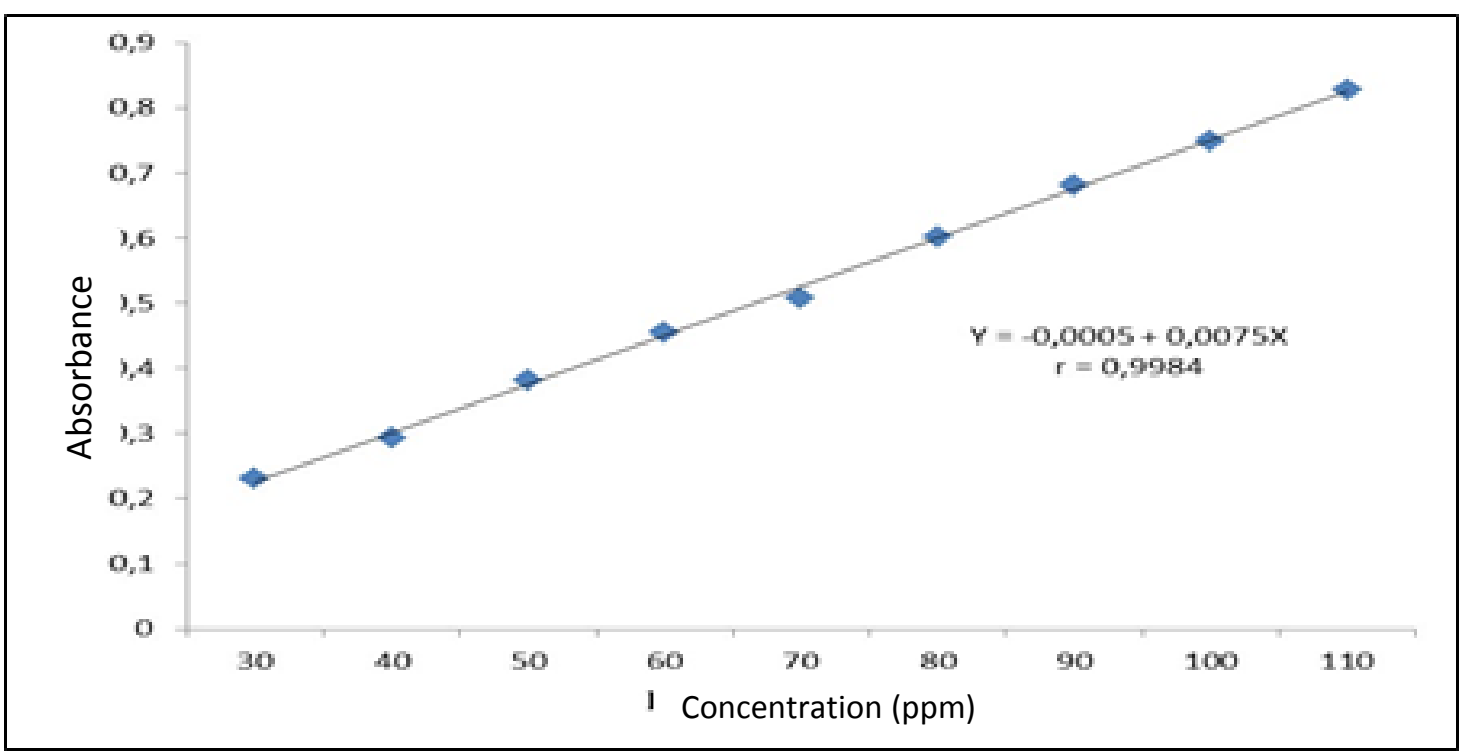

Figure 6. The calibration curve of quercetin at a wavelength of $435.5 \mathrm{~nm}$

The total flavonoid content in this study was determined based on the colorimetric method (Change et al., 2002) that the sample solution in methanol was reacted with $\mathrm{AlCl}_{3}$ and $\mathrm{CH}_{3} \mathrm{COOK}$ and diluted with aquadest. Silencing of the solution in a dark place because complex compounds that are formed are sensitive to light. $\mathrm{AlCl}_{3}$ solution is used to form color complexes with flavonoids and $\mathrm{CH}_{3} \mathrm{COOK}$ to stabilize the complex bonds formed. 

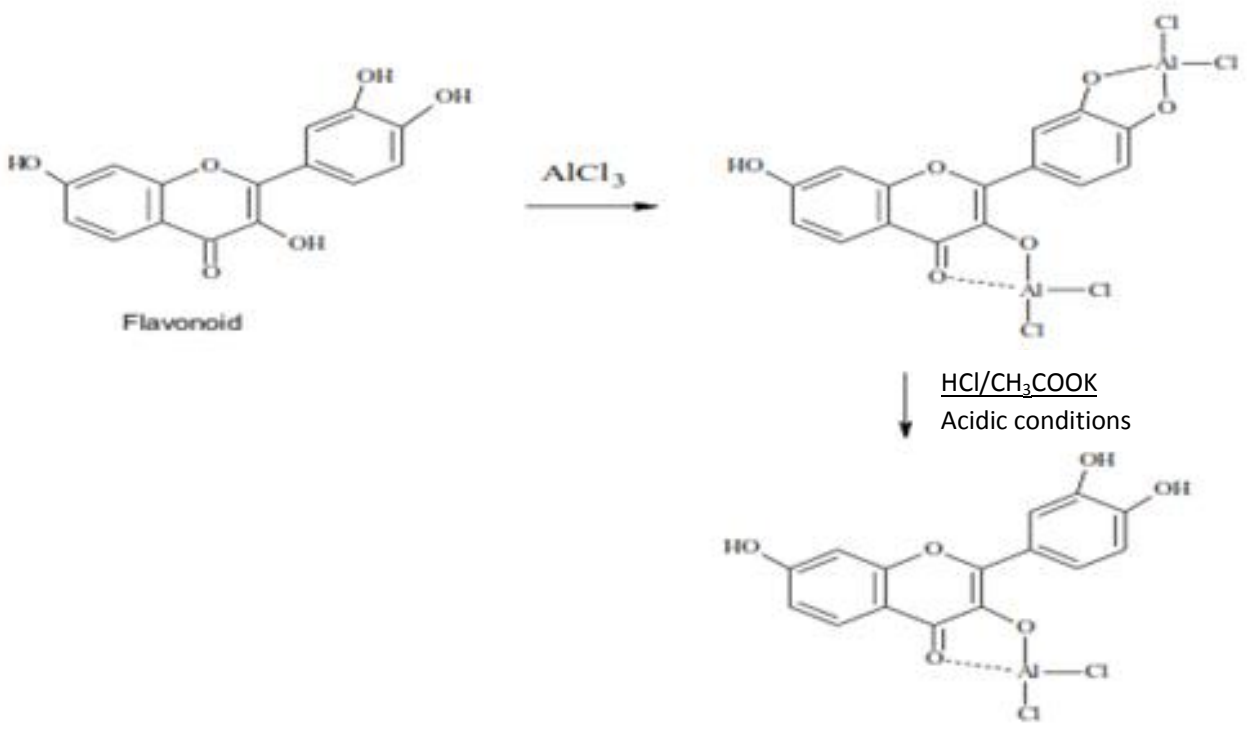

Figure 7. Reaction of the formation of flavonoid complex compounds with $\mathrm{AlCl}_{3}$ (Mabry et al., 1970)

The principle of the analysis of total flavonoids using $\mathrm{AlCl}_{3}$ (Lewis acids) that form stable complexes with acid C-4 ketone group, and the C-3 or C-5 hydroxyl of flavones and flavonols. The principle of determination is based on the dihydroxy ortho group and the hydroxy ketone group which forms the $\mathrm{AlCl}_{3}$ reagent complex so as to provide a batochromic effect. The results of determining total flavonoid concentrations with quercetin standard solutions can be seen in table 2 .

Table 2. The results of total flavonoid determination of ethanol extract of taro leaf stalks

\begin{tabular}{|c|c|c|c|c|c|}
\hline Samples & Replication & Triplo & $\begin{array}{c}\text { Concentrations } \\
\text { (mgQE/gram) }\end{array}$ & $\begin{array}{c}\text { Average } \pm \text { SD } \\
\text { (mgQE/gram) }\end{array}$ & $\mathrm{CV}(\%)$ \\
\hline \multirow{9}{*}{$\begin{array}{l}\text { Ethanol } \\
\text { extract of } \\
\text { taro leaf } \\
\text { stalks }\end{array}$} & \multirow{3}{*}{1} & 1 & 10,2290 & \multirow{3}{*}{$10,2363 \pm 0,0080$} & \multirow{3}{*}{0,0790} \\
\hline & & 2 & 10,2450 & & \\
\hline & & 3 & 10,2350 & & \\
\hline & \multirow{4}{*}{2} & 1 & 10,2510 & \multirow{3}{*}{$10,2437 \pm 0,0080$} & \multirow{3}{*}{0,0789} \\
\hline & & 2 & 10,2450 & & \\
\hline & & 3 & 10,2350 & & \\
\hline & & 1 & 10,1950 & \multirow{3}{*}{$10,1870 \pm 0,0080$} & \multirow{3}{*}{0,0785} \\
\hline & \multirow[t]{2}{*}{3} & 2 & 10,1870 & & \\
\hline & & 3 & 10,1790 & & \\
\hline
\end{tabular}

Total flavonoid content equivalent to QE (Equivalent Quercetin). The results in Table II show the average total flavonoid

\section{Conclusion}

Ethanol extract of taro leaf stalks (Colocasia esculenta [L.] Schott) contains concentrations of $10.2223 \mathrm{mgQE} /$ gram with $\% \mathrm{CV}$ value of $0.3051 \%$.

flavonoids with total flavonoid concentrations of $10.2223 \mathrm{mgQE} /$ gram with $\%$ CV value of $0.3015 \%$. 


\section{References}

Achmad, S.A., 1986, Kimia Organik Bahan Alam, Karnunika, Jakarta

Ahmad, A.R., Juwita.,dan Ratulangi, S.A.D., 2015, Penetapan Kadar Fenolik dan Flavonoid total ekstrak Metanol Buah dan Daun Patikala (Etlingera elatior (Jack)R.M.SM), Jurnal Pharm. Sci Res vol. 2 No 1

Arum,Y.P., Supartono., Sudarmin., 2012, Isolasi dan Uji Daya Antimikroba Ekstrak Daun kersen, Jurnal MIPA

Biren, N.S., Nayak, B.S., Bhatt, S.P., Jalalpure, S.S., dan Seth, A.K., 2007, The Anti-Inflamatory Activity of The Leaves of Colocasiaesculenta, Screening of Plant, Jurna No 1. 15. 3-4

Chang, C.C., Yang, M.H., Wen, H.M., dan Chern, J.C., 2002, Estimation oftotal flavonoid content in propolis by two complementary colorimetric methods, J Food Drug Anal 10:178182

Dalimartha, S., 2006, Atlas Tumbuhan Obat Indonesia Jilid 4, Puspa Swara, Jakarta

Dwidjoseputro, D., 1994, Dasar-Dasar Mikrobiologi, Djambatan, Jakarta

Fadlila, W.N., Yuliawati, K.M., dan Syafnir, L., 2015, Identifikasi Senyawa Aktif Antibakteri dengan Metode Bioautografi KLT terhadap Ekstrak Etanol Tangkai Daun Talas (ColocasiaEsculentaL) Schott, Jurnal Prosiding Penelitian Universitas Islam Bandung
Harmita, 2004, Petunjuk Pelaksanaan Validasi Metode dan Cara perhitungannya, Majalah Ilmu Kefarmasian Vol. 1, Departemen Farmasi FMIIPA, Universitas Indonesia

Mabry, T.J., Markham, K.R., and Thomas, M.B., 1970, TheSystematic identification offlavonoid, Springer-Verlag, Berlin, 50-52

Marliana, S.D., Suryanti,V, dan Suyono,2005, Skrining Fitokimia dan Analisis Kromatografi Lapis Tipis Komponen Kimia Buah Labu Siam (Sechium edule Jacq. Swartz.) dalam Ekstrak Etanol. Jurnal Biofarmasi. 3 (1): 26-31

Miller, A.L., 1996, Antioxidant flavonoids: structure, function, and clinical usage alternative medical Review 1:103 - 111

Riyanto, A., 2009, Pengolaban dan Analisis Data Kesehatan, Nuha Medika, Yogyakarta

Voight, R., 1995, Buku Pelajaran Teknologi Farmasi, diterjemahkan oleh Soendari Noerono, Gajah Mada University Press, Yogyakarta, 561

Wijaya, B.A, Citraningtyas Gayatri, dan Wehantouw Frenly, 2014, Potensi Ekstrak Etanol Tangkai Daun Talas (Colocasia EsculentaL) sebagai alternative Obat Luka Pada Kulit Kelinci (Oryctolagus Cuniculus), Jurnal Ilmiah Farmasi-UNSRAT Manado: Program Studi Farmasi FMIPA UNSRA 